\title{
Methane emissions, economic growth and agriculture: evidence of environmental kuznets curve for Argentina
}

\section{Emisiones de metano, crecimiento económico y agricultura: evidencia de la curva ambiental de kuznets para Argentina}

Jessica Lissette Sánchez Cruz

Luis Eduardo Solis Granda

Manuel Leonardo Perrazo Viteri

Universidad Estatal de Milagro-UNEMI, Ecuador

Autor para correspondencia: 1solisg@unemi.edu.ec; mperrazov@unemi.edu.ec; jsanchezc5@unemi.edu.ec

Fecha de recepción: 10 de abril de 2018 - Fecha de aceptación: 15 de septiembre de 2018

\begin{abstract}
This paper provides evidence of the existence of an Environmental Kuznets Curve (EKC) in the long-run for Argentina from 1970 to 2012 which is the country with most production of meat in the region. There is a dynamic relationship between methane emissions, economic growth and agriculture activities. The autoregressive distributed lag methodology was used to test for cointegration in the long-run. Furthermore, we used the vector error correction model to test for causality and to verify the predictive value of independent variables. In fact, a quadratic relationship was found between methane emissions and economic growth. The effect of agriculture was the only unexpected, and that is because the reduction of methane emissions thanks to suitable policies related to the use of technology in agriculture activities.
\end{abstract}

Key words: environmental kuznets curve; ardl; Argentina; methane emissions, gdp; agriculture JEL Code: C32, Q01, Q50, Q51, Q56

Resumen: Este documento proporciona evidencia de la existencia de una curva ambiental de Kuznets (EKC) a largo plazo para Argentina desde 1970 hasta 2012, que es el país con mayor producción de carne en la región. Existe una relación dinámica entre las emisiones de metano, el crecimiento económico y las actividades agrícolas. La metodología de retraso distribuido autorregresivo se utilizó para probar la cointegración a largo plazo. Además, utilizamos el modelo de corrección de errores vectoriales para probar la causalidad y verificar el valor predictivo de las variables independientes. De hecho, se encontró una relación cuadrática entre las emisiones de metano y el crecimiento económico. El efecto de la agricultura fue el único inesperado, y esto se debe a la reducción de las emisiones de metano gracias a políticas adecuadas relacionadas con el uso de la tecnología en las actividades agrícolas.

Palabras clave: curva de kuznets ambiental; ardl; argentina; emisiones de metano; pib; agricultura 


\section{Introduction}

The Kuznets Curve was proposed by Simon Kuznets in 1955. He found that there was an existence of a quadratic relationship between economic growth and income inequality. Inequality rises up along with economic growth until a turning point in which the trend inverts (Kuznets, 1955). The same explanation was used to describe the environmental degradation relating a Green House Gases (GHG) such as carbon dioxide (CO2), methane $(\mathrm{CH} 4)$ or Nitrous Oxide (N2O) with an economic growth variable such as Gross Domestic Product. As long as a country increases its gross domestic product, its GHG emissions will increase as well, until a turning point in which technology makes a country more efficient in the way the anthropogenic activities are done and the emissions of those gases start to reduce (Kraft and Kraft, 1978).

Since Kuznets discovery, several different countries were studied to provide empirical evidence of the existence of an EKC. Besides GDP, other variables related to environmental degradation were included in the models over time, including foreign trade (Hossain, 2011), urbanization (Zhang and Cheng, 2009) and energy consumption (Saboori and Sulaiman, 2013).

There are few studies that demonstrate an EKC with a methane emissions and GDP per capita relationship, but in this paper we are going to show that GDP per capita and agriculture have an inverted U-shaped relationship.

As shown in figure 1, methane emissions are the second largest GHG emissions in the world (IPCC, 2014), and they are principally generated as a result of agriculture and livestock farming activities. Argentina is one of the largest producers of meat in the region (INTA, 2014) with around 51 million cattle. Agriculture is the third principal economic activity in Argentina, accounting for around 10\% of the total gross domestic product (MECON, 2012).

Those are the reasons that motivate us to study the Argentinian case and found the existence of an EKC for the period of 1970 to 2012.

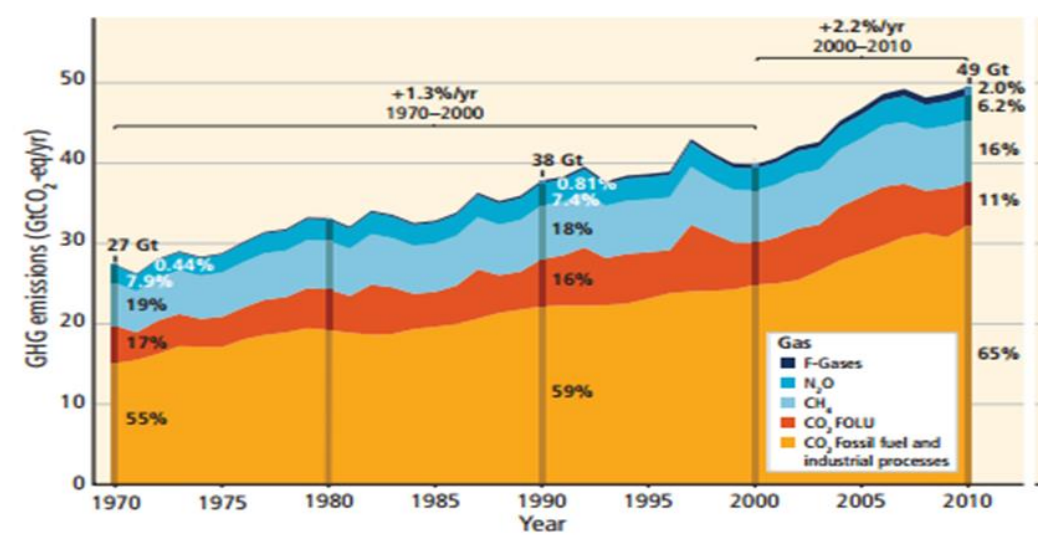

Figure 1: Total annual anthropogenic GHG emissions by gases 1970-2010 Source: IPCC, 2014

The methodology used is an autoregressive distributive lag (ARDL) bounds testing approach to cointegration with a series time analysis from 1970 to 2012. Results show an EKC for the short-run as well as for the long-run. As expected, agriculture is statistically significant; 
however, in the long run has a negative impact on emissions, due to Argentinian environmental policies and the incremental technology used for those activities.

The rest of the paper is organized as follows: Section 2 explains the environmental and economic situation of Argentina. Section 3 defines the theoretical and modeling framework. Section 4 presents the methodology to be used. Section 5 shows the empirical results. Section 6 concludes.

\section{Argentine Context.}

Argentina is a South American country with a population of 41.45 million people, of which almost $10 \%$ are rural population (WBG, 2013). Argentina is the third largest economy in South America, just behind Brazil and Chile. Its average growth rate of real gross domestic product (GDP) per capita was 2.55\% between 1980 and 2012, as shown in figure 2 (MECON, 2012). Argentina has a Gini coefficient of 0.423 (WBG, 2013) and a Score of 0.836 in human development (United Nations Development Program, 2014). Both scores are improving over time, illustrating the improvement in Argentinian living conditions as a result of economic growth.
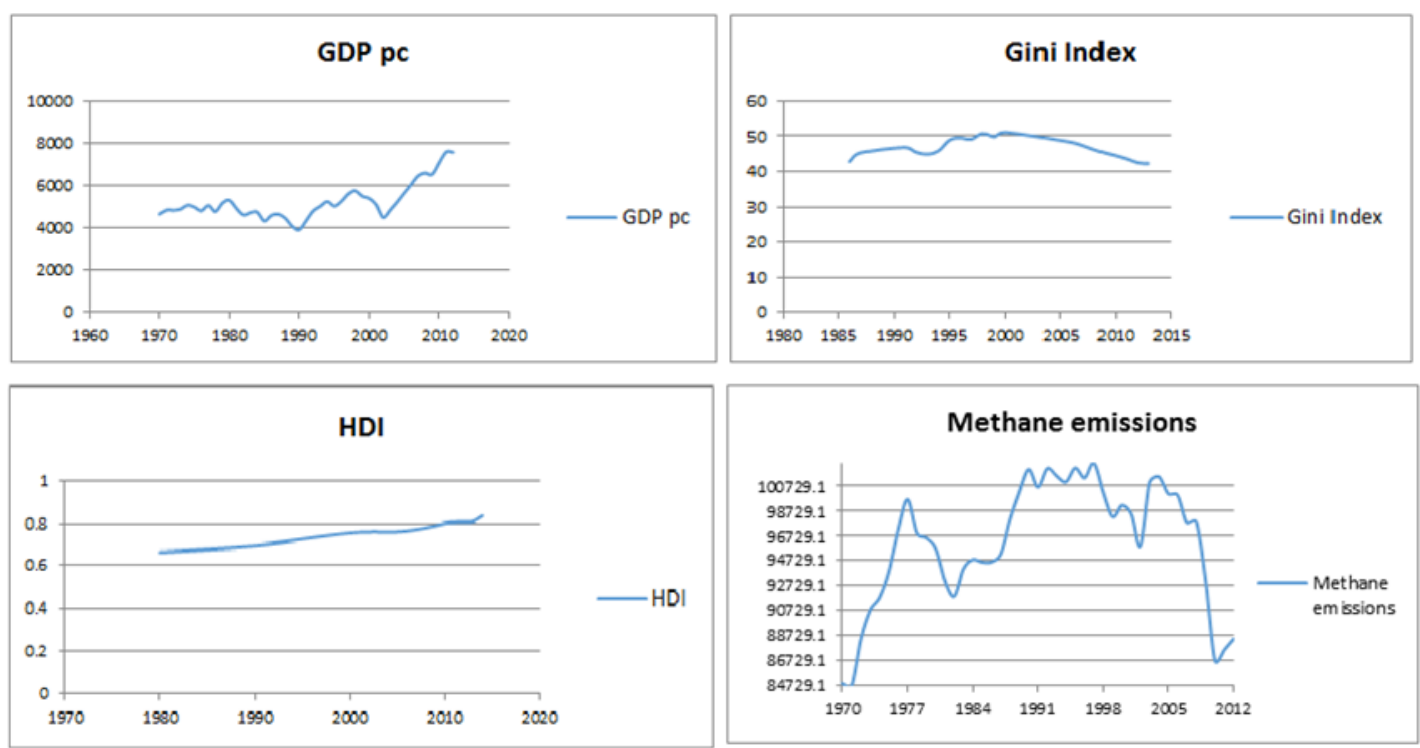

Figure 2: Graphic representations of GDP pc, Gini Index, HDI and Methane emissions for Argentina

In the environmental context, Carbon Dioxide (Co2) is the GHG most produced because of the human activity, but in this paper we're going to focus on the second GHG most emitted, methane (CH4). Methane, in general, is generated as a result of anthropogenic activities, principally agriculture. According to the World Bank Group data, Argentina and Brazil produce the most meat in the region, and also emit the most methane from livestock farming activities.

Agriculture and livestock farming contribute $44 \%$ of total GHG emissions in the country, just behind the energy sector (Berra, 2000) with $48 \%$ of total methane emissions. Of the total GHG emissions, 30\% comes from livestock farming, and 95\% of that comes from cattle (IICA, 2015). Livestock farming contributes to the methane emissions from enteric fermentation and excretions of animals. These last two are also a source of nitrous oxide, just as nitrogen-fixing fodder. In 
agricultural activities, these emissions occur as a result of nitrogen-fixing crops, including soybeans and Stubble. Commercial fertilizers also contribute to the emission of nitrous oxide, while rice cultivation generates methane emissions. Finally, burning Stubble produces nitrous oxide emissions, other nitrogen oxides, carbon monoxide and methane.

Even though methane is the second largest GHG in Argentina, its emissions have been reduced as a result of an increase in the technology used in agriculture and livestock farming, as shown in figure 2.Argentina had to apply Innovative processes and change macroeconomics policies in order to let the rural population to begin a process of economic and productive recovery. This growth is accompanied by sustainable development policies for agricultural and rural sector. The Agri-Food and Agribusiness Strategic Plan (PEA2) and the Smart Agriculture Plan (AI) were created in order to generate a more efficient, competitive and sustainable production. Promoting smart agriculture involves developing active policies in the agricultural sector to harmonize production and environmental systems, while at the same time representing the Argentine government's response to the challenge of food security in the context of climate change.

\section{Theoretical and modeling framework}

The EKC hypothesis indicates that the relationship between economic growth and environmental degradation has an inverted $U$ shape.In the short-run, the economic growth of a country has a negative impact on the environment seen in the rising part of the curve; but in the long-run, when the economy reaches its highest point of income, known as the turning point, the curve descends, illustrating the positive impact of economic growth on the environment.

The model is structured as follows

$\operatorname{Ln}(\mathrm{Et})=\beta \_(0)+\beta \_1 \mathrm{Ln}(\mathrm{Yt})+\beta \_2 \llbracket(\mathrm{Ln}(\mathrm{Yt})) \rrbracket \wedge 2+\beta \_3 \quad(\operatorname{Ln}(\mathrm{Yt})) \rrbracket \wedge 3+\beta \_4 \mathrm{Ln} \llbracket\left(\mathrm{Z} \rrbracket \_\mathrm{t}\right)+\mu \mathrm{t}$

Where the dependent variable is an indicator of environmental contamination measured in logarithms, $\beta 0, \beta 1, \beta 2, \beta 3$ are the parameters to be estimated, $\mathrm{Y}$ is the per capita income in logarithms, $\mathrm{Z}$ is the vector of additional variables, also measured in logarithms and finally $\mu$ is the error term.

This work suggest in the equation 1 that methane emissions (CH4) depend on GDP, square of GDP (GDP^2) and the agriculture (AGRI) for the period 1970-2012 in the case of Argentina.

$$
\llbracket \mathrm{CH} \rrbracket+4=\mathrm{f}(\mathrm{GDP}, \llbracket \mathrm{GDP} \rrbracket \wedge 2, \mathrm{AGRI})
$$

The model would be as follows:

$$
\operatorname{Ln}\left(\llbracket \mathrm{CH} \rrbracket \_4\right)=\beta \_(0)+\beta \_1 \mathrm{Ln}(\mathrm{GDP})+\beta \_2 \llbracket(\operatorname{Ln}(\mathrm{GDP})) \rrbracket \wedge 2+\beta \_3 \operatorname{Ln}(\mathrm{AGRI})+\mu \mathrm{t}
$$

The theory suggests that in order to get an EKC, this should have the following relationship:

$\llbracket \beta \rrbracket \_1>0, \beta_{-} 2<0$ which have the shape of an inverted U. It is expected that $\beta \_$GDP $>0$ and $\beta \_$ 
$\left(\mathrm{GDP}^{\wedge} 2\right)<0$; the sign of $\beta \_\mathrm{AGRI}>0$ if we assume that activities concerning agriculture are handled without any significant technological improvement during the period analyzed.

The data on all variables come from World Development Indicators (WDI). The methane emissions ( $\left.\llbracket \mathrm{CH} \rrbracket \_4\right)$ is proxied by Methane emissions (kt of CO2 equivalent), the GDP per capita (constant 2005 US\$) and AGRI is for Agriculture, value added (\% of GDP).

\section{Methodology}

\section{ARDL Bounds Testing of Cointegration}

The application of the ARDL bounds testing approach to cointegration developed by Pesaran and Pesaran (1997), Pesaran et al. (2000, 2001) allows us to examine the long-run relationship between methane emission, economic growth and the agricultural.

The methodology used is the Auto regressive model with distributed lags which was proposed by Pesaran et al. (2001), which provides better results for small samples as proposed by Haug (2002), less than 50 data samples, such as the proposed case. This model also can be applied without investigation the order of integration, but a requirement is that they should not be at second difference I(2). The ARDL model provides better results with this type of samples, compared to traditional approaches to cointegration, like Engle and Granger Granger (1987), Johansen and Juselius (1990) and Phillips and Hansen (1990). Laurenceson and Chai (2003) affirm that another advantage of ARDL limit testing is that the model is not restricted model error correction (ECM), and has sufficient flexibility to accommodate lags that capture the data generating process in a general framework of specification.

The unrestricted model is indicated as follows:

$$
\begin{aligned}
\Delta \ln C H_{4 t}=\alpha_{0} & +\beta_{G D P} \ln G D P_{t-1}+\beta_{G D P^{2}} \ln G D P^{2}{ }_{t-1}+\beta_{A G R I} \ln A G R I_{t-1} \\
& +\sum_{i=1}^{m} \alpha_{i} \Delta \ln C H_{4 t-i}+\sum_{j=0}^{m} \alpha_{j} \Delta \ln G D P_{t-j}+\sum_{k=0}^{n} \alpha_{k} \Delta \ln G D P_{t-k}^{2} \\
& +\sum_{l}^{n} \alpha_{l} \Delta \ln A G R I_{t-l}+\mu_{t}
\end{aligned}
$$

In order to determine whether there is cointegration of the variables, it is necessary to use the critical values tabulated by Pesaran et al. (2001), where the null hypothesis of no cointegration is $\beta \_\mathrm{GDP}=\beta \_\left(\mathrm{GDP}^{\wedge} 2\right)=\beta \_\mathrm{AGRI}=0$ and the alternative hypothesis that represents cointegration of the variables is $\beta \_$GDP $\neq \beta \_\left(G^{\prime} P^{\wedge} 2\right) \neq \beta \_A G R I \neq 0$. With this, we can obtain the F-calculated which is compared with the upper and lower critical bound values from Pesaran et al. (2001). Another option is to use the critical values proposed by Narayan (2005) as these are more appropriate for small samples, as in our case. If the value of F-calculated exceeds the critical value, then we have evidence that the variables are cointegrated. On the other hand, if the F-statistic is less than the critical value, we cannot reject the null hypothesis of no cointegration. Finally, if the calculated Fstatistic is between lower and upper critical bounds, the cointegration decision is not conclusive. If the null hypothesis of no cointegration is rejected, the behavior of the variables in the short-run 
will be captured by the error correction term 『(ECT】_ $(\mathrm{t}-1))$ incorporated in equation 3as follows:

$$
\begin{aligned}
\Delta \ln C H_{4 t}=\delta_{1} & +\sum_{i=1}^{p} \delta_{1 i} \Delta \ln C H_{4 t-i}+\sum_{j=0}^{q} \delta_{2 j} \Delta \ln G D P_{t-j}+\sum_{k=0}^{m} \delta_{3 k} \Delta \ln G D P_{t-k}^{2} \\
& +\sum_{l}^{n} \delta_{4 l} \Delta \ln A G R I_{t-l} \\
& +\gamma E C T_{t-1}+\mu_{t}
\end{aligned}
$$

The coefficient of ECT $(\gamma)$ indicates the speed of adjustment and shows how quickly the variables return to the long-run equilibrium (Masih and Masih, 1997), that coefficient should be negative and significant.

Finally, diagnostic tests are performed to check the suitability of the model, including the Jarque-Bera normality test, Breusch-Godfrey serial correlation LM test, ARCH hetoscedasticity test, Ramsey RESET test and cumulative sum/- squared (CUSUM/CUSUMSQ) test.

\section{Causality Analysis}

The presence of cointegration between variables implies that the causal relation must exist at least in one direction; the ARDL model does not show what the causality direction is. In order to explain the causality in the short run and long run of the variables it is necessary to apply a vector error correction model (VECM) to examine for cointegrated variables.

VECM permits to analyze two forms of causality. One of them is the short-run causal relationship and the other one is the long-run causal relationship. It is necessary, in order to get a short-run granger-causal relationship, for the lagged differenced explanatory variables to be significant. To get a long-run granger causal relationship, it is necessary for the lagged ECT to be significant, as well. (Masih and Masih, 1996).

In this case, Estimate the residuals of the long-run model as a proxy of the ECT is the first step. Then, as a second step, we need to estimate the VECM as follows:

$$
\begin{gathered}
{\left[\begin{array}{c}
\Delta \ln C H_{4 t} \\
\Delta G D P_{t} \\
\Delta G D P_{t}^{2} \\
\Delta A G R I_{t}
\end{array}\right]=\left[\begin{array}{l}
\mu_{1} \\
\mu_{2} \\
\mu_{3} \\
\mu_{4}
\end{array}\right]+\left[\begin{array}{lll}
\tau_{11,1} & \tau_{12,1} & \tau_{13,1} \tau_{14,1} \\
\tau_{21,1} & \tau_{22,1} & \tau_{23,1} \tau_{24,1} \\
\tau_{31,1} & \tau_{32,1} & \tau_{33,1} \tau_{34,1}
\end{array}\right]} \\
{\left[\begin{array}{c}
\Delta \ln C H_{4 t-1} \\
\Delta G D P_{t-1} \\
\Delta G D P_{t-1}^{2} \\
\Delta A G R I_{t-1}
\end{array}\right]+\left[\begin{array}{l}
\sigma_{1} \\
\sigma_{2} \\
\sigma_{3} \\
\sigma_{4}
\end{array}\right] E C T_{t-1}+\left[\begin{array}{l}
\vartheta_{1} \\
\vartheta_{2} \\
\vartheta_{3} \\
\vartheta_{4}
\end{array}\right]}
\end{gathered}
$$

Where the vector of $\vartheta$ t's is white noise.The okare interpreted as the speed of adjustment which represent the response of the dependent variable to deviations from the long-run equilibrium. 


\section{Empirical Results}

According to Ouattara (2004), if a variable is integrated into I (2), then the F-statistic for the cointegrating is inconclusive.It is necessary that the variables become stationary until I(1). We use the ADF unit root test to check the stationarity of our variables. The results show that there are not unit root problems. Table 1 indicates that all variables are non-stationary at level, but these become stationary at the first difference.

The selection of the maximum lag length for each variable has been determined using the SIC (Schwarz information criteria) in which the minimum value is taken. Table 2 presents several of the combination sets of lags, including the one chosen for the model $(1,0,0,1)$.

The next step is the calculation of F-statistic cointegration, as shown in Table 3. The results indicate that the calculated value is above the upper bound of 3.454 obtained through critical values proposed by Narayan (2005). It is concluded thata cointegration relationship exists between methane emissions, GDP, 【GDP】_2 and AGRI, when methane emissions is the dependent variable. Table 3 also shows the results of the respective diagnostic tests.

The long-run estimates are reported in Table 4. The results show that the coefficients of the variables are significant. While the values for GDP and GDP_2are the expected, the AGRI coefficient is contrary to the expected. In this case heteroskedasticity and serial autocorrelation was detected; we will work with robust errors of white and residues laggards one period to deal with both problems respectively. All the coefficients are significant at $1 \%$. The estimations in the long-run show the existence of an EKC in Argentina. The methane emissions increase when income does, until a turning point and then the emissions start to decrease while income continues to rise. The long-run elasticity between methane missions and agriculture is $-0.058 \%$. This means that a $1 \%$ rises in agriculture, the methane emissions decrease by $-0.058 \%$.

The short-run model is shown in Table 5. The AGRI variable is significant at $1 \%$ as the error correction term, wherein the coefficient of the latter is shown negative; this confirms the existence of the cointegrating equation. Moreover, the coefficient of ECT means that the deviations from equilibrium methane are corrected by $28.18 \%$ within a year.

The causality based on VECM is reported in Table 6. There are two portion of this table. The first portion is showing the short- run causality (F-statistic). The second portion presenting the long-run causality indicated through significance of ECT (t-statistic). The short run causal effects revealed that the agriculture is the only variable that has effect on methane emissions, The short run causal effects revealed that the agriculture is the only variable that has effect on methane emissions, while in the long run the results indicate that there is a bidirectional causality in all variables.

To verify this, the variance decomposition was implemented, Table 7 shows the results which indicates that; a change in one standard deviation in GDP, GDP2 and AGRI represents a shock of the $26.23 \%, 22.10 \%$ and $30.71 \%$ respectively in $\mathrm{CH} 4$ emissions. Given that these shocks are higher if it was contrary $(0.23 \%, 0.22 \%, 10.52 \%)$, then there is an unidirectional Granger causality of the variables to $\mathrm{CH} 4$. 
The CUSUM and CUSUMQ are used to check the stability of the coefficients for the short and long-run. Figures 2 and 3 show that the coefficients are stable with a significance level of 5\%. The results suggest that the model can be used for policy proposal.

Table 1: Unitroot test

\begin{tabular}{llc}
\hline Table 1: Unitroot test & & \\
Variable & T-Statistics & P value* \\
\hline ADF test at level with intercept and without trend & & \\
& & \\
Ln CH4t & -2.0837 & 0.252 \\
LnGDPt & -0.6068 & 0.8580 \\
Ln GDPt2 & -0.5588 & 0.8687 \\
LnAGRIt & -2.8324 & 0.0624 \\
ADF test at first difference with intercept and without trend & & \\
& & \\
$\Delta$ Ln CH4t & -4.9075 & 0.0002 \\
$\Delta$ LnGDPt & -5.0591 & 0.0002 \\
$\Delta$ Ln GDPt2 & -5.0375 & 0.0002 \\
$\Delta$ LnAGRIt & -6.6400 & 0.0000 \\
$*$ MacKinnon (1996) considered P values & & \\
\hline
\end{tabular}

Table 2: Lag Length selection criteria

\begin{tabular}{llll}
\hline \multicolumn{2}{l}{ Table 2: Lag Length selection criteria } & & \\
Lagcombination & SIC & F-statistic & P value \\
\hline$(2.2 .2 .2)$ & -4.085603 & 2.1388 & 0.0468 \\
$(2.0 .1 .0)$ & -4.256634 & 2.170226 & 0.0507 \\
$(2.0 .0 .2)$ & -4.344973 & 2.785578 & 0.014012 \\
$(2.0 .0 .1)$ & -4.40326 & 2.97092 & 0.010657 \\
$(2.0 .0 .0)$ & -4.345665 & 2.475947 & 0.030139 \\
$(1.1 .1 .1)$ & -4.415757 & 3.529861 & 0.003156 \\
$(1.0 .1 .0)$ & -4.302162 & 2.555225 & 0.025157 \\
$(1.0 .0 .2)$ & -4.409142 & 3.005556 & 0.00998 \\
$(1.0 .0 .1)$ & -4.520785 & $4.021315 * *$ & 0.001729 \\
$(1.0 .0 .0)$ & -4.391765 & 2.960585 & 0.013467 \\
SIC: Schwarz information criteria, **indicates statistical significance at 5\% level \\
\hline
\end{tabular}

Table 3: Cointegrationtestsresults

\begin{tabular}{ll}
\hline $\begin{array}{l}\text { Table 3: Cointegrationtestsresults } \\
\text { Boundstesting to cointegration }\end{array}$ \\
\hline Estimatedequation & CH4=f(GDP, GDP2, AGRI) \\
Optimallagstructure & SIC: Schwarzinformationcriteria \\
F-statistics & $3.532992 * * *$ \\
Diagnosticcheck & \\
R2 & 0.5386 \\
Adjusted-R2 & 0.4047 \\
F-statistics (P) & 4.0213 \\
J-B Normality test & 0.6934 \\
Breusch-Godfrey LM test [2] & 1.5870 \\
\hline
\end{tabular}




\begin{tabular}{|c|c|c|c|}
\hline \multicolumn{4}{|l|}{ ARCH LM test [2] } \\
\hline \multicolumn{4}{|l|}{ Ramsey RESET } \\
\hline \multicolumn{4}{|l|}{ CUSUM } \\
\hline \multicolumn{4}{|c|}{$\begin{array}{l}\text { CUSUMSQ Stable } \\
* * * \text { The significant at } \mathbf{1 0 \%} \text { level. The optimal structure is determined by SIC }\end{array}$} \\
\hline \multicolumn{4}{|c|}{ SIC: Schwarzinformationcriteria } \\
\hline \multicolumn{4}{|c|}{ Table4: Long run estimates } \\
\hline \multicolumn{4}{|c|}{ Table4: Long run estimates } \\
\hline \multicolumn{4}{|c|}{ Dependent variable $=\mathrm{Ln} \mathrm{CH} 4 \mathrm{t}$} \\
\hline Variable & Coefficient & Standard error & T-statistic \\
\hline Constant & -7.2360 & 6.6444 & -1.089042 \\
\hline LnGDPt & 4.5249 & 1.5425 & $2.933441 *$ \\
\hline Ln GDP2t & -0.27157 & 0.089593 & $-3.03114 *$ \\
\hline LnAGRIt & -0.058341 & 0.015759 & $-3.702024 *$ \\
\hline \multicolumn{4}{|l|}{ Diagnosticcheck } \\
\hline R-squared & 0.816254 & & \\
\hline Akaikeinfocriterion & -4.6340 & & \\
\hline Schwarzcriterion & -4.4272 & & \\
\hline F-statistic & 41.0913 & & \\
\hline Durbin-Watson & 1.61607 & & \\
\hline Serial correlation LM [2] & 1.2463 & & \\
\hline ARCH test [2] & 0.0846 & & \\
\hline Normality test & 1.1439 & & \\
\hline $\begin{array}{l}\text { Ramsey RESET test } \\
* 1 \% \text { level of significance }\end{array}$ & 0.4262 & & \\
\hline
\end{tabular}

Table 5: Short run estimates

\begin{tabular}{llll}
\multicolumn{4}{l}{ Table 5: Short run estimates } \\
\multicolumn{4}{l}{ Dependent variable= $\boldsymbol{\Delta}$ Ln } \\
CH4t & & & \\
Variable & Coefficient & Standard error & T-statistic \\
\hline Constant & 0.001519 & 0.003091 & 0.49142 \\
$\Delta$ LnGDPt & 1.285262 & 3.390862 & 0.379037 \\
$\Delta$ Ln GDPt2 & -0.072553 & 0.199407 & -0.363845 \\
$\Delta$ LnAGRIt & -0.026913 & 0.017582 & -1.530678 \\
ECT(-1) & -0.281883 & 0.085189 & $-3.308902^{*}$ \\
Diagnosticchecks & & & \\
R-squared & 0.491924 & & \\
Akaikeinfocriterion & -4.988632 & & \\
Schwarzcriterion & -4.696071 & & \\
F-statistic & 5.486531 & & \\
Durbin-Watson & 1.903009 & & \\
Serial correlation LM [2] & 0.4643 & & \\
ARCH test [2] & 0.0222 & & \\
Normality test & 0.3433 & & \\
\hline
\end{tabular}




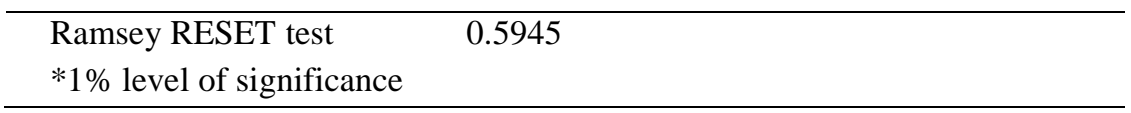

Table 6: Causality results based on VECM.

\begin{tabular}{|c|c|c|c|c|c|}
\hline \multirow[t]{2}{*}{ Variable } & \multicolumn{4}{|c|}{ Short Run (F-stat.) } & \multirow{2}{*}{$\begin{array}{l}\text { Long run (t-stat.) } \\
\text { ECT }\end{array}$} \\
\hline & $\Delta \ln (\mathrm{CH} 4)$ & $\Delta \ln ($ GDP) & $\Delta \ln (G D P 2)$ & $\Delta \ln ($ AGRI) & \\
\hline$\Delta \ln (\mathrm{CH} 4)$ & - & $\begin{array}{c}0.851638 \\
(4.075853)\end{array}$ & $\begin{array}{c}0.870510 \\
(0.240178)\end{array}$ & $\begin{array}{l}15.41688 * * * \\
(0.018777)\end{array}$ & $\begin{array}{l}-2.132135 * * \\
(0.079872)\end{array}$ \\
\hline$\Delta \ln ($ GDP $)$ & $\begin{array}{l}3.794231 \\
(0.388378)\end{array}$ & - & $\begin{array}{c}2.766037 \\
(0.639166)\end{array}$ & $\begin{array}{c}0.024518 \\
(0.049969)\end{array}$ & $\begin{array}{l}3.077004 * * * \\
0.252556\end{array}$ \\
\hline$\Delta \ln ($ GDP2) & $\begin{array}{c}3.956387 \\
(6.588783)\end{array}$ & $\begin{array}{c}2.752860 \\
(184.0129)\end{array}$ & - & $\begin{array}{c}0.025557 \\
(0.847712)\end{array}$ & $\begin{array}{l}3.094094 * * * \\
3.605982\end{array}$ \\
\hline$\Delta \ln ($ AGRI) & $\begin{array}{c}0.939578 \\
(1.206945)\end{array}$ & $\begin{array}{c}0.000897 \\
(33.70782)\end{array}$ & $\begin{array}{c}0.003157 \\
(1.986306)\end{array}$ & - & $\begin{array}{l}-2.422722 * * \\
0.660550\end{array}$ \\
\hline $\begin{array}{l}* * \text { Significan } \\
* * * \text { Significa } \\
\end{array}$ & $\begin{array}{l}5 \% \text { level. } \\
\text { t } 1 \% \text { level. }\end{array}$ & & & & \\
\hline
\end{tabular}

Table 7: Error VarianceDecomposition

\begin{tabular}{|c|c|c|c|c|c|}
\hline \multicolumn{6}{|c|}{$\begin{array}{l}\text { Table 7: Error VarianceDecomposition } \\
\text { Variance Decomposition of } \Delta \ln (\mathrm{CH} 4) \text { : }\end{array}$} \\
\hline Period & S.E. & $\Delta \ln (\mathrm{CH} 4)$ & $\Delta \ln (\mathrm{GDP})$ & $\Delta \ln (\mathrm{GDP} 2)$ & $\Delta \ln (\mathrm{AGRI})$ \\
\hline 1 & 0.017924 & 100 & 0 & 0 & 0 \\
\hline 2 & 0.025177 & 88.81764 & 0.014629 & 7.425548 & 3.742183 \\
\hline 3 & 0.027707 & 85.75045 & 4.236748 & 6.785603 & 3.227198 \\
\hline 4 & 0.030826 & 77.24769 & 10.8478 & 6.644078 & 5.260431 \\
\hline 5 & 0.034713 & 65.94547 & 15.15791 & 8.530882 & 10.36573 \\
\hline 6 & 0.039347 & 53.78145 & 18.36229 & 11.75429 & 16.10197 \\
\hline 7 & 0.044972 & 42.47137 & 21.01229 & 15.28986 & 21.22648 \\
\hline 8 & 0.051341 & 33.36988 & 23.16881 & 18.19393 & 25.26738 \\
\hline 9 & 0.058277 & 26.35869 & 24.9032 & 20.39408 & 28.34403 \\
\hline 10 & 0.065763 & 20.96539 & 26.22884 & 22.10349 & 30.70228 \\
\hline \multicolumn{6}{|c|}{ Variance Decomposition of $\Delta \ln (G D P)$ : } \\
\hline Period & S.E. & $\Delta \ln (\mathrm{CH} 4)$ & $\Delta \ln (\mathrm{GDP})$ & $\Delta \ln (\mathrm{GDP} 2)$ & $\Delta \ln (\mathrm{AGRI})$ \\
\hline 1 & 0.052967 & 1.563922 & 98.43608 & 0 & 0 \\
\hline 2 & 0.08043 & 1.027026 & 92.07062 & 0.589216 & 6.313138 \\
\hline 3 & 0.097611 & 0.714228 & 81.57238 & 2.705943 & 15.00745 \\
\hline 4 & 0.115068 & 0.655445 & 67.73927 & 8.614837 & 22.99045 \\
\hline 5 & 0.132993 & 0.554025 & 56.40919 & 14.96274 & 28.07405 \\
\hline 6 & 0.149031 & 0.44595 & 49.53755 & 19.17593 & 30.84058 \\
\hline 7 & 0.163801 & 0.369199 & 45.51527 & 21.70486 & 32.41067 \\
\hline 8 & 0.178447 & 0.311324 & 42.92245 & 23.28829 & 33.47794 \\
\hline
\end{tabular}




\begin{tabular}{llllll}
\hline $\mathbf{9}$ & 0.193417 & 0.265764 & 41.00211 & 24.37428 & 34.35784 \\
$\mathbf{1 0}$ & 0.20885 & 0.228767 & 39.42088 & 25.21497 & 35.13538
\end{tabular}

\begin{tabular}{llllll}
\multicolumn{6}{l}{ Variance Decomposition of $\Delta \ln ($ GDP2): } \\
Period & S.E. & $\Delta \ln (\mathrm{CH} 4)$ & $\Delta \ln (\mathrm{GDP})$ & $\Delta \ln (\mathrm{GDP} 2)$ & $\Delta \ln (\mathrm{AGRI})$ \\
$\mathbf{1}$ & 0.89965 & 1.522484 & 98.45155 & 0.02597 & 0 \\
$\mathbf{2}$ & 1.37085 & 1.051577 & 91.77875 & 0.792375 & 6.377295 \\
$\mathbf{3}$ & 1.668548 & 0.736277 & 81.07585 & 3.071479 & 15.11639 \\
$\mathbf{4}$ & 1.972737 & 0.651917 & 67.13369 & 9.100331 & 23.11406 \\
$\mathbf{5}$ & 2.2856 & 0.541912 & 55.7987 & 15.45998 & 28.19941 \\
$\mathbf{6}$ & 2.566035 & 0.433508 & 48.95958 & 19.63881 & 30.9681 \\
$\mathbf{7}$ & 2.824543 & 0.357789 & 44.98036 & 22.12314 & 32.53871 \\
$\mathbf{8}$ & 3.080823 & 0.301136 & 42.43513 & 23.66076 & 33.60297 \\
$\mathbf{9}$ & 3.34263 & 0.256776 & 40.56335 & 24.70324 & 34.47663 \\
$\mathbf{1 0}$ & 3.6124 & 0.220851 & 39.02898 & 25.5043 & 35.24587
\end{tabular}

\section{Variance Decomposition of $\Delta \ln ($ AGRI):}

\begin{tabular}{llllll} 
Period & S.E. & $\Delta \ln (\mathrm{CH} 4)$ & $\Delta \ln (\mathrm{GDP})$ & $\Delta \ln (\mathrm{GDP} 2)$ & $\Delta \ln (\mathrm{AGRI})$ \\
$\mathbf{1}$ & 0.163402 & 3.651318 & 0.68262 & 17.82866 & 77.8374 \\
$\mathbf{2}$ & 0.197369 & 6.481976 & 9.538751 & 12.27059 & 71.70868 \\
$\mathbf{3}$ & 0.203531 & 6.827817 & 11.42669 & 13.41201 & 68.33348 \\
$\mathbf{4}$ & 0.208048 & 7.68437 & 11.0265 & 15.83099 & 65.45814 \\
$\mathbf{5}$ & 0.215282 & 8.958847 & 11.17903 & 18.44538 & 61.41675 \\
$\mathbf{6}$ & 0.220193 & 9.68185 & 11.65538 & 19.85527 & 58.8075 \\
$\mathbf{7}$ & 0.222258 & 10.08876 & 12.23311 & 19.93336 & 57.74477 \\
$\mathbf{8}$ & 0.223702 & 10.36469 & 12.65993 & 19.67769 & 57.29769 \\
$\mathbf{9}$ & 0.225526 & 10.50875 & 12.97685 & 19.56565 & 56.94875 \\
$\mathbf{1 0}$ & 0.228005 & 10.51623 & 13.33153 & 19.63535 & 56.51688 \\
\hline
\end{tabular}

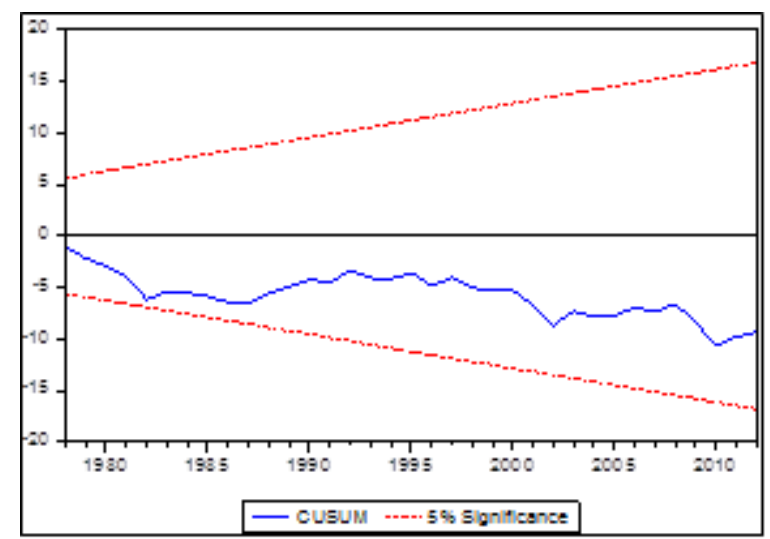

Figure3: Plot of cumulative sum of recursive residuals 


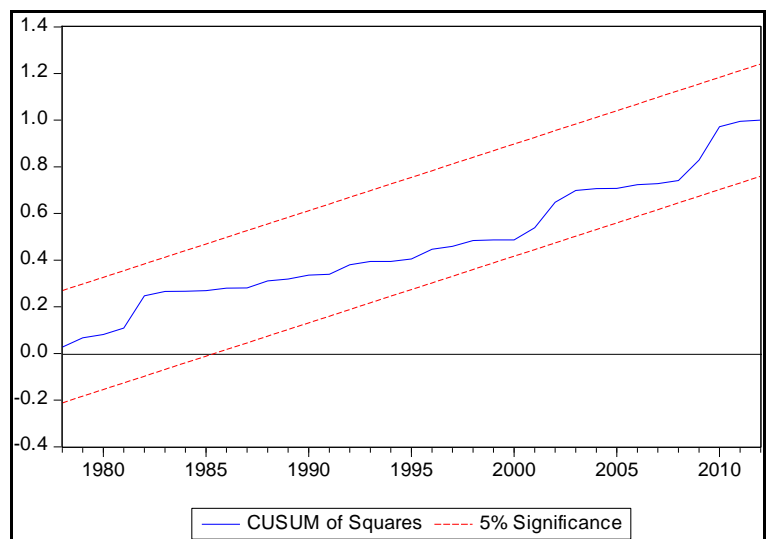

Figure 4:Plot of cumulative cum of squares of recursive residuals

\section{Conclusion and policy implications}

The objective of this paper was to empirically examine the short-run and long-run relationships of methane emissions, GDP per capita, and agriculture in Argentina for the period of 1970-2012. Using the ARDL model proposed by Pesaran et al, (2001) we observed that the coefficients of the variables GDP and 【GDP』^2 were positive and negative respectively, suggesting the existence of an inverted curve U-shape. Assuming that there is indeed an Environmental Kuznets Curve (EKC) in Argentina, and considering the publication of Stern et al. (1996), we cannot conclude that economic growth can improve the environment, but we should consider policies that have been established in Argentina to achieve sustainable development.

Contrary to expectations, the coefficient of agriculture variable was negative; this can be justified with the technological innovations employed in the agricultural sector in this country, the Agri-Food and Agribusiness Strategic Plan (PEA2) and the Smart Agriculture Plan (AI).

Countries whose economic policies induce a rapid expansion of income and employment may experience serious environmental damage unless appropriate environmental regulations are taken Dasgupta (2002). Martin (2002) came to the same conclusion, that the Environmental Kuznets Curve can only be expected when the respective measures are taken.

The existence of ECK in Argentina shows changes of a growing economy in which appropriate technologies have been implemented to reduce the environmental impact.

\section{Bibliography}

Basso, L. R., C. Pascale Medina, E. S. de Obschatko, J. Preciado Patiño, 2013. Agricultura Inteligente: la iniciativa de la Argentina para la sustentabilidad en la producción de alimentos y energía.

Ministerio de Agricultura, Ganadería y Pesca de la Nación, Instituto Interamericano de Cooperación para la Agricultura. Buenos Aires, 124 pp.

Berra Guillermo. (2000), Influencia de la ganadería argentina: Emisión de Gases de Efecto Invernadero. 
INTA. Castelar, 1-4.

CEPAL, FAO, IICA(2014) Perspectivas de la agricultura y del desarrollo rural en las Américas: una mirada hacia América Latina y el Caribe. San José, C.R.: IICA, 2013. 230 p.

Dasgupta, S., Laplante, B., Wang, H., and Wheeler, D. (2002).Confronting the Environmental Kuznets Curve. The Journal of Economic Perspectives, Vol. 16, No. 1.Edited by Winkler, H., Davidson, O.,

Kenny, A., Prasad, G., Nkomo, J., Sparks, D., Howells, M., and Alfstad, T. (2006).

Engle, R.F., Granger, C.W.J. (1987), Cointegration and error correction representation: estimation and testing. Econometrica, 55, 251-276.

Hossain, S. (2011), Panel estimation for CO2 emissions, energy consumption, economic growth, trade openness and urbanization of newly industrialized countries.EnergyPolicy, 39, 69916999.

IICA, (2015). Cambio climático y agricultura en la Argentina: aspectos institucionales y herramientas de información para la formulación de políticas. Edith S. de Obschatko. Buenos Aires.

IPCC, 2014: Climate Change 2014: Synthesis Report. Contribution of Working Groups I, II and III to the Fifth Assessment Report of the Intergovernmental Panel on Climate Change [Core Writing Team, R.K. Pachauri and L.A. Meyer (eds.)]. IPCC, Geneva, Switzerland, 151 pp.

Johansen, S., Juselius, K. (1990), Maximum likelihood estimation and inference on cointegration with applications to the demand for money. Oxford Bulletin of Economics and Statistics, $52,169-210$.

Kraft, J., Kraft, A. (1978), On the relationship between energy and GNP. Journal of Energy and Development, 3, 401-403.

Kuznets, S. (1955), Economic growth and income inequality. The American Economic Review, $45,1-28$.

Laurenceson, J., Chai, J.C.H. (2003), Financial Reforms and Economic Development in China. Cheltenham, UK: Edward Elgar.

Masih, A.M.M., Masih, R. (1997), on temporal causal relationship between energy consumption, real income and prices: some new evidence from Asian energy dependent NICs based on a multivariate cointegration vector error correction approach. Journal of Policy Modeling, 19, 417-440. 
Martin, Christoph. (2002). The Environmental Kuznets Curve: A survey of the empirical evidence and possible causes.

Ministerio de Economía y Finanzas, (2012). La Macroeconomía Argentina: 2003-2012. Buenos Aires.

Narayan, P.K. (2005), the saving and investment nexus for China: evidence from cointegration tests.

Applied Economics, 37, 1979-1990.

Newey, W.K., West, K.D. (1987), a simple, positive semi-definite heteroskedasticity and autocorrelation consistent covariance matrix. Econometrica, 55, 703-708.

Ouattara, B. (2004), The Impact of Project Aid and Programme Aid on Domestic Savings: a Case Study of Cote d'Ivoire." Centre for the Study of African Economies Conference on Growth, Poverty Reduction and Human Development in Africa

Pesaran, M.H., Pesaran, B. (1997), Working with Microfit 4.0: Interactive Econometric Analysis. Oxford: Oxford University Press.

Pesaran, M.H., Shin, Y., Smith, R.J. (2000), Structural analysis of vector error correction models with exogenous I(1) variables. Journal of Econometrics, 97, 293-343.

Pesaran, M.H., Shin, Y., Smith, R.J. (2001), Bounds testing approaches to the analysis of level Relationships. Journal of Applied Econometrics, 16, 289-326.

Phillips, P.C.B., Hansen, B.E. (1990), Statistical inference in instrumental variables regression with I (1) processes. Review of Economic Studies, 57, 99-125.

Saboori, B., Sulaiman, J. (2013), Environmental degradation, economicgrowth and energy consumption: Evidence of the environmental Kuznets curve in Malaysia. Energy Policy, 60, 892-905.

Shahbaz, M., Dube, S., Ozturk, I., Jalil A. (2015), Testing the Environmental Kuznets Curve Hypothesis in Portugal. Energy, 5(2), 2146-4553.

Stern D.I, Common, M., Barbier, E. (1996), Economic growth and environmental degradation: the environmental Kuznets curve and sustainability. World Development, 24, 1151-1160.

White, H., 1980, Aheteroskedasticity-consistent covariance matrix and a direct test for heteroskedasticity, Econometrica 48, 817-838.

World Bank, Group, (2006). Argentina: Agriculture and Rural Development: Selected Issues, Washington D.C. 40-70. 
World Development Indicators (WDI).(2014), World Bank. Available from: http://www.data.worldbank.org/data-catalog/world-development-indicators/wdi-2016.

Zhang, X.P., Cheng, X.M. (2009), Energy consumption, carbon emissions, and economic growth in China. Ecological Economics, 68, 2706-2712 